кандидат філософських наук, доцент (Житомирський державний університет імені Івана Франка) chaplinskay@ukr. net ORCID: 0000-0002-9702-6906

\title{
ФІЛОСОФСЬКИЙ ДИСКУРС СВІТУ ТВАРИНИ М. ХАЙДЕГГЕРА
}

У статті здійснено філософську рефлексію світу тварини у курсі лекиій 1929-1930 рр. М. Хайдегzера. Визначено, що його феноменологічно-екзистенціалістський аналіз тварини розкриває ї̈ навколишнє середовище через тезис "тварина бідна у світі (weltam)", що реалізується у негативний спосіб через позбавлення, а властивий ій спосіб буття розуміється як заиіпеніння (Bепоттеnheit) і є умовою поведінки. Онтологічний статус тварини усвідомлюється ним як відкритість без розкриття.

Ключові слова: М. Хайдегzер, феноменологія тварини, "тварина бідна у світі", заціпеніння, відкритість без розкриття.

Постановка проблеми. Філософія другої половини XX ст. поступово відмовляється від пріоритету стратегії, за якою людина вважається домінантою у дослідницьких методологіях, що власне згодом оприявнюється у кризі антропоцентричного мислення. До того ж спонукою до перегляду питання про людину стали артикуляційні процеси, котрі відсікали сферу природного (первинна артикуляція) або накладали заборону на будь-які трансцендентні пояснення (вторинна артикуляція). Констатація і розуміння того, що "людина - це ім'я серії процедур, що виникли внаслідок переконфігурацій диспозитивів знання і влади" [1:199] актуалізує вимогу філософського переосмислення біному людина / тварина. Рухома відмінність останнього зумовлює втрату ним статусу універсального принципу розмежування простору, водночас констатуючи нагальність осмислення низки інших проблем, зокрема метафізичних засад статусу й ролі тварин. Варто наголосити, що друга половина XX ст. акцентувала проблему тварини настільки, що попередні здобутки не змогли в повній мірі задовольнити запити і дати грунтовні відповіді тогочасним викликам.

Аналіз основних досліджень і публікацій. Світ тварин стає предметом філософської рефлексії М. Хайдеггера під час прочитання лекцій під загальною назвою "Основні поняття метафізики. Світ Кінечність - Самотність" у зимовому семестрі 1929-1930рp. у Фрайбурзькому університеті. У предметне поле його дослідження для всебічного аналізу втрапляють різні живі організми: амеба, інфузорія, муха, бджола, нічний метелик, черви, кроти, ящірки, риби, морські їжаки, білки, птахи і домашні тварини, зокрема собаки. Хайдеггерівський дискурс тварини, з одного боку, став засадничим для праць тих філософів, які прагнуть після "смерті Бога" і падіння метафізичного гуманізму повернути визначення i значення людини, протиставляючи їі тварині, а з іншого, він вагомий для тих, хто намагається осмислити відношення, етику, політику й онтологію у неатропоцентричних або транс-, або пост-гуманістичних термінах. Висловлені ним думки отримали наступний розвиток у працях Д. Агамбена, Ж. Батия, Ж. Дельоза, Ж. Дерріди, Ф. Гваттарі, С. Елден, Ж.-Л. Нансі, М. Каларко, К. Корсгард, А. Клері, Е. Левінаса, Т. Рігана, Ж. Сімондона, П. Сінгера, М. Фуко, що зумовило виникнення самостійної філософської дисципліни - animal philosophy (у дослівному перекладі - філософія тварин, хоча, як зазначає О. Гомілко, "дана проблематика у нас відсутня, а відповідно, і іiі термінологія" [2: 262]). Антропологізація тварини помножена на деконструвістський аналіз обгрунтували введення поняття, що фіксує специфічні взаємини людини і тварини - "буття з тваринами" (being with animals) (Ж. Дерріда). Зміна етичних засад у відношенні до тварини, феноменологічний досвід розуміння іiі як Іншого, а подекуди олюднення (humanisation) тварини сприяють перетворенню проблем світу тварин у самодостатній предмет філософської рефлексії. Право на життя і право не страждати стають максимою у відношенні людини до тварини.

Мета статті - філософська рефлексія світу тварини у творчості М. Хайдеггера (на прикладі "Основних понять метафізики. Світ - Кінечність - Самотність").

Виклад основного матеріалу. Філософський аналіз світу тварини ситуативно або паралельно з іншою проблематикою презентований у конкретній епістемі, що пояснюється не тільки невизначеністю й розмитістю співвідношення людини і тварини, але й складністю перекладу та етимології відповідних лексем у різних мовах, зокрема, грецької, латинської, німецької та французької (див. [3: 402-406]). Давньогрецька континуалістська онтологія живого спродукувала троїстий поділ. Аристотелівська ієрархія живого розгортається від найнижчого рівня, тих, чия душа наділена здатністю лише харчуватись $\mathrm{i}$ самовідтворюватись (рослини), але не відчувати та рухатись (animaux "тварини" в нашому сенсі), мислити та говорити (людей). За критерієм спроможність / не спроможність проживати у спільноті громадян маємо поділ звір / людина / бог, де той, хто не здатен в спільноті жити "звір", "страховисько", а той, кому нема потреби у ній жити "бог" [3: 403]. Дискретна отологія за часів християнства, грунтуючись на метафізичному поділі матерія / життя / дух, номінує тварину у статусі живого, але позбавленого душі / духу. 3 одного боку, 
середньовічна філософія популяризує запропоновану стоїками ідею про те, що рослини й тварини створені для користі людини, а з іншого - християнський антропоцентризм, легітимувавши домінантність людини, зумовив ігнорування настанови піклуватися про тварин.

Варто наголосити, що розгортання біному людина / тварина реалізувалось на засадах таких етичних принципів як альтруїзм або ж егоїзм/ прагматизм, але в жодному з них не відбувалось потрактування тварини як Іншого. Крім того, тоталізуюче мислення європейської філософської традиції нівелювало саму проблему Іншого, оскільки вбачало в ньому негативний момент і воліло не бачити й не чути його. Суттєво змінюється розуміння Іншого у філософському дискурсі XX ст., що дозволяє окреслити наступні концептуально-методологічні підходи до Іншого феноменологічно-екзистенціалістський, психоаналітичний і діалогічний. Між Я та Іншим формується асиметричний характер зв'язку, при цьому інтерпретація Іншого не обмежується виключно дійсною живою людиною. Рефлексивно-пізнавальний характер світосприйняття доповнюється комунікативно-моральним i врешті-решт психоаналітичним аспектом. Філософська рефлексія щодо тварини кардинально змінюється з усвідомленням людиною відповідальності щодо усього живого і, як наслідок, послаблюється пріорітетність над світом тварин.

Як відомо, базовими для становлення філософії тварини вважаються ідеї Мартіна Хайдеггера. Розуміння ним фігури тварини реалізовувалось на засадах тогочасних біолого-зоологічних міркувань (врахувавши небезпеку віталізму і механіцизму у розумінні тварини, його філософський аналіз грунтується на здобутках Й. Мюллера й Я. Юкскеля) і в горизонті осмислення способів буття у відношенні до світу. Хайдеггерівська фундаментальна онтологія, 3 одного боку, не змогла подолати домінантну ідею тотальності, яка фактично усувала Іншого і виправдовувала насильство щодо нього, а з іншого - створила основну інтенцію: усвідомлення неминучої смертності і кінечності буття людини. Спродукована ним метафізика сутність світу фіксує через такі тезиси "камінь (матеріальне) без світу (weltlos)", "тварина бідна у світі (weltarm)" і "людина в світі рішень (weltbildend)". Опинившись між двома іншими, тезис "тварина бідна у світі" вимагає уточнення у якому сенсі тварина "бідна світом", адже з'ясування цього передбачає окреслення не тільки кількісного "менше", воно одночасно апелює до самого поняття "світу", що виражає не кількість, не суму і не ступінь доступності сущого. М. Хайдеггер визначає "світ - це те чи інше доступне суще, з яким так чи інакше поводяться; це щось таке, що доступне, і з чим можливо або - для певного способу буття сущого - необхідно те або інше поводження" [4]. Вихідний пункт міркувань філософа щодо тварини й обділеності світом виглядає так: "якщо під "світом" ми розуміємо суще у тій чи іншій доступності і якщо доступність сущого є основною характеристикою світу, тоді тварина, оскільки вона має доступ до Іншого, виявляється на боці людини. Тоді тварина і людина мають світ. 3 іншого боку, якщо проміжний тезис тварина бідна у світі має право на існування, якщо бідність- це позбавлення, а позбавлення - це не-мати, тоді тварина виявляється на стороні каменю, який, будучи без світу, світу не має... Але такий результат або суперечить самому собі і тому неможливий, або, формулюючи проблему "тварина має світ і не має світу" [4]. Після того, як філософ таким негативним способом - через позбавлення - дає визначення навколишньому середовищу тварини, він ставить собі за мету визначити іiі специфічний онтологічний статус.

Властивий їй спосіб буття М. Хайдеггер номінує як заціпеніння (Benommenheit), що є умовою поведінки (sich benehmen), тобто можливості того, щоб тварина поводила себе відповідно до власної сутності у певному навколишньому середовищі. "Отже, заціпеніння (Benommenheit) тварини означає: сутнісну позбавленість (Genommenheit) у неї якого б то не було сприйняття чогось як чогось, а тому за такої віднятості має місце залученість-до (Hingenommenheit-durch)... отже, заціпеніння тварини означає, перш за все, модус буття при якому тварина у своїх відношеннях з іншими позбавлена можливості або, як ми ще кажемо, у неї відібрана (Benommen) можливість вступати у відносини і відноситись до цього іншого як такого, як до присутнього, як до сущого" [4]. Він наголошує, що зустріч тварин з об'єктами навколишнього середовища активує інстинктивні реакції, продукуючи в цілому серію концептуально неопосередкованих дій, що ув'язнені в коло інстинктів. Тому поведінка тварини - "це інстинктивний "гон" (das Treiben), який як би вказує на те, що всі повадки тварини характеризуються "гнаністю" (die Getriebenheit), спричиненою інстинктивним спонуканням (das Triebhafte) [4]. Ïї існування якщо чимось і охоплене, то виключно відокремленістю від світу, внаслідок чого воно визначається як "бідна у світі" (weltarm), хоча і не "без світу" (weltlos). Тварина все-таки знаходиться в ставленні до Іншого, тобто має доступ до- в сенсі іiі інстинктивної поведінки. У ній поєднується володіння світом і не-володіння ним, спосіб іiі буття визначається тим, що вона володіє доступом до-. Сприйняття інших істот тваринами розгортається на засадах "виробництва ефектів присутності", наше спільне буття таке, що ми дозволяємо їй обертатись у нашому світі [4]. Визначений німецьким філософом спосіб буття тварини є деякою формою відкритості, котра однак ніколи не розкриває світ тварині як суще. Її онтологічний статус визначається як відкритість (offen) без розкриття (offenbar). Міркуючи про відкрите як одне з імен буття, Дж. Агамбен продовжує думки М. Хайдеггера і констатує: "Суще для тварини відкрите, але недоступне; тобто воно відкрите у недоступності і непрозорості, тобто певною мірою в деякому не-відношенні. Ця відкритість без розкритості i характеризує обділеність тварини світом, тоді як людина характеризується 
світоформуванням. Тварина не зовсім позбавлена світу, оскільки у своєму заціпенінні вона відкрита йому, i - на відміну від каменя, зовсім позбавленого світу ій має його не вистачати (entbehren), і саме тому у своєму бутті вона може бути визначена через обділеність і нестачу" [5: 67-68]. Проте, "тварина бідна у світі" у жодному разі не означає, що іiі життя має меншу цінність чи становить собою нижчий ступінь порівняно з людським Dasein.

Досвід світу наперед визначених взаємозв'язків інтерпретується як присутність, фундаментальними рисами якої є екзистенція, фактичність, падіння. М. Хайдеггер аналізує екстатичність присутності, яка вже сформована. Людина, як онтологічна структура, віднаходить себе існуючою у вже визначеному світі, тому модусом іï присутності $\epsilon$ Dasein. Натомість тварина може тільки просто бути, вона не спроможна розуміти себе в якості існуючого, їй властивий інший, специфічний модус існування. Для німецького філософа очевидним є факт, що деякі тварини спроможні нести певні компоненти модуса буття Dasein (наприклад, концептуально опосередковане схоплювання навколишнього середовища), однак тварини не є Dasein. Крізь призму відносини між живою істотою і Dasein, відбувається усвідомлення того, що animalitas втрачає звичні риси і стає тим, що найважче мислити, а humanitas трансформується у щось невловиме. Відтак, феноменологія світу тварини, як то не парадоксально, продукує більше інформації про людину.

Аналізуючи фігуру чи фігури тварин у широкому ракурсі спадщини М. Хайдеггера, С. Елден стверджує, що різниця між твариною і людиною сконцентрована у фундаментальній відмінності, за якою "... людина це zoon logon ekhon. Ця фраза Аристотеля стала метафізичною засадою поняття тваринної раціональності, але Хайдеггер стверджує, що тварина повинна бути зрозуміла як живе буття, пов'язане 3 логосом, мовленням, і охоплене ним. Розуміння логосу як мовлення, а не розуму, ratio, - це ключове положення глобального проекту Хайдеггера" (переклад мій - О. Ч.) [6: 100]; "Тварина відмінна від людини, яка є zoоn logon ekhon. Саме з цих причин тварини не живуть або не проживають; вони також не дивляться [blicken], а скоріше поглядають, спостерігають, витріщають очі або видивляються, оскільки це не "саморозкриття буття", ніщо не відкривається їм; так само, домашній пес насправді не "їсть" і насправді не співвідносить себе зі столом, під яким знаходиться, або зі сходами, якими біжить" (переклад мій - О. Ч.) [6: 104]. Відмінність між людським буттям-у-світі і буттям-у-світі тварини у працях М. Хайдеггера отримує радикальне і чітке розмежування, у кожному прикладі "тварини конституюються через відсутність, нестачу того чи іншого: вони обділені світом, антиісторичні, наділені phone, але не мають logos i, як наслідок, не спроможні указувати, вони не вмирають, не переживають простір як простір, не живуть, не наділені руками" [6: 108], а людині іманентні такі фундаментальні характеристики, як мовлення, історичність, проект, турбота, калькуляція. Останнє поняття дозволяє стверджувати про еволюцію людини до технізованої тварини, що стало можливим завдяки ratio, тобто тріумфу числа. Людина як раціональна тварина означає насправді те, що люди - ті, ким не можуть бути тварини. "Це значить, що людина може те, чого ніколи не зможе тварина, тобто спуститися нижче тварини, оскільки до справи залучені калькуляція і розум" [4]. М. Хайдеггер вважав, що засадничою для політичної детермінації світу стає його редукція до числа, калькулятивна політика націлена як на людину, так і на тварину, що в свою чергу актуалізує питання про права тварини, про визнання ії (починаючи з 1970-х рр. з’являється низка праць, у яких критикується експлуататорське поводження 3 тваринами, а їх інтереси трактуються через їхню здатність відчувати страждання). Таким чином, у своєму зимовому курсі лекцій німецький філософ окреслив кілька шляхів осмислення біному людина / тварина, що стали фундаментом для animal philosophy.

Висновки та перспективи подальших досліджень проблеми. Феноменологічно-екзистенціалістський опис буття тварини виявляє в його специфіці форму виклику людині, форму питання про ії власний світ. Не викликає сумнівів кінцеве твердження М. Хайдеггера: "Тому тезис "тварина бідна у світі" повинен залишитися проблемою - проблемою, за вирішення якої тепер ми не беремося, але яка скеровує наші подальші кроки в порівняльному аналізі, тобто скеровує експозицію проблеми світу як таку" [4]. Наразі праксеологічна складова філософії тварини презентована здобутками в межах онтологічної, етичної і правової складових. Таким чином, закликаючи до радикальної відповідальності за всі форми життя, М. Хайдеггер окреслив нагальність розробки нових способів мислення та життя з тваринами, що наразі залишається відкритою проблемою.

\section{СПИСОК ВИКОРИСТАНИХ ДЖЕРЕЛ ТА ЛІТЕРАТУРИ}

1. Петренко Д. В. Артикуляція природи в контексті філософської антропології / Д. В. Петренко // Гілея. - 2015. Випуск 99. - С. 197-199.

2. Ольга Гомілко Світ тварини у сучасному філософському дискурсі : ідентичність та освітні перспективи [Електронний ресурс]/О.Гомілко // Визначальні виміри сучасного філософськоантропологічного знання. Зб. наук. праць: Філософсько-антропологічні студії. - 2013. - Київ : Стилос. C. 261-271. - Режим доступу : https://www.filosof.com.ua/Conference/zbirka_2013-1.pdf.

3. Європейський словник філософій : Лексикон неперекладностей. - Пер. 3 фр. - Том другий. - К. : ДУХ I ЛIТЕРА, 2011. $-488 \mathrm{c}$.

4. Хайдеггер М. Основные понятия метафизики : Мир-Конечность- Одиночество [Електронный ресурс] / Мартин Хайдеггер. - Режим доступа : https://fil.wikireading.ru/30015. 
5. Джордано Агамбен Открытое / Агамбен Джордано / Пер. с итал. и нем. Б. М. Скуратова. - Москва : РГГУ, $2012-112 \mathrm{c}$.

6. Стюарт Элден Животные Хайдеггера / С. Элден // Хора - 2008. - № 3. - С. 98-112.

\section{REFERENCES (TRANSLATED\&TRANSLITERATED)}

1. Petrenko D. V. Artukuliatsiia pryrody v konteksti filosofskoi antropolohii [Articulation of Nature in the Context of Philosophical Anthropology] / D. V. Petrenko // Hileia [Hileia] - 2015. - Vypusk 99. - S. 197-199.

2. Olha Homilko Svit tvaryny u suchasnomu filosofskomu dyskursi : identychnist' ta osvitni perspektyvy [World of Animals in Modern Philosophical Discourse : Identity and Educational Perspectives] [Elektronnyi resurs]/ O. Homilko// Vyznachalni vymiry suchasnoho filosofsko-antropolohichnoho znannia [Definitive Dimensions of Modern Philosophical and Antropological Knowledge]. - Zb. nauk. prats' : Filosofsko-antropolohichni studii, 2013.Kyiv : Stylos. - S. 261 -271. - Rezhym dostupu : https://www.filosof.com.ua/Conference/zbirka_2013-1.pdf.

3. Yevropeiskyi slovnyk filosofii : Leksykon neperekladnostei [European Dictionary of Philosophy : Lexicon of NonInterpretation]. - Per. $\mathrm{z}$ fr. - Tom druhyi. - K. : DUKh I LITERA, 2011. - $488 \mathrm{~s}$.

4. Haydegger M. Osnovnyie ponyatiia metafiziki : Mir - Konechnost' - Odinochestvo [Basic Concepts of Metaphysics : the World - of Course - Loneliness] [Elektronnyi resurs]/ Martin Haydegger. - Rezhym dostupu : https://fil.wikireading.ru/30015.

5. Dzhordano Ahamben Otkrytoe [Open] / Ahamben Dzhordano / Per. s ital. i nem. B. M. Skuratova. - Moskva : RHHU, $2012-112 \mathrm{~s}$

6. Stiuart Elden Zhyvotnyie Khaidehhera [Heidegger's Animals] / S. Elden // Khora - 2008. - № 3. - S. 98-112.

\section{Чаплинская О. В. Философский дискурс мира жниотного М. Хайдегzера.}

В статье проанализированы философские размышления М. Хайдеггера о животном в курсе лекций 1929 1930 гг.. Определено, что феноменологически-экзистенциальный анализ животного раскрывает его окружающий мир через тезис "жсивотное скудомирно (weltam)", что реализуется негативным способом через лишенность, а свойственный ему способ бытия понимается как очепенение (Bепоттепhеit) $u$ служит основой для поведения. Онтологический статус животного осознается им как открытость без раскрытости.

Ключевые слова: М. Хайдеггер, феноменология животного, "энивотное скудомирно", оцепенение, открытость без раскрытости.

\section{Chaplinska O. V. Philosophical Discourse of M. Heidegger's Animal World.}

Philosophy of the second half of the twentieth century stated the urgency of rethinking the binomial man / animal to change the ambiguity towards the latter. Phenomenological experience of understanding it as the other contributed to the transformation of the problems of the animal world into a self-sufficient subject of philosophical reflection, which predetermined the emergence of an independent discipline on the present day. Ideas of Martin Heidegger are considered to be basic for the philosophy of the animal. His understanding of animal figure was based on the biological and zoological achievements of that time and in the horizons of understanding the ways of being in relation to the world. He captures the essence of the world through the following theses: "stone (material) without world" (weltlos)", "the poor animal in the world (weltarm)" and "man in the world of solutions (weltbildend)". The thesis for the existence of an animal involves some form of openness, which, however, never reveals the animal's world as being. Its ontological status is defined as openness (offen) without disclosure (offenbar). M. Heidegger denotes the inherent animal way of being as numbness Benommenheit, which is a condition of behaviour (sich benehmen), that is, the ability to behave in accordance with one's own being in a particular environment. However, "the poor animal in the world" does not in any way mean that its life is of less value. The difference between human being-in-the-world and animal being-in-the-world in M. Heidegger's works receive a clear distinction between which the animal is constituted by the absence and lack of fragility of the world, while the human is imparted to such fundamental characteristics as speech, historicity, design, care and calculation. Taking into consideration the fact that some animals are able to carry certain components of the mode of being of Dasein, M. Heidegger emphasizes that the animals are not Dasein. Through the prism of the relationship between the living being and Dasein, there is an awareness that animalitas loses its usual features and becomes what is hardest to think, and humanitas is transformed into something intangible. Hence, the phenomenology of the animal world has produced more information about human being. Heidegger's animal discourse called for radical responsibility for all forms of life and highlighted the urgency of developing new ways of thinking and living with animals, which is now an open issue.

Key words: M. Heidegger, phenomenology of the animal, "the poor animal in the world", numbness, openness without disclosure. 